
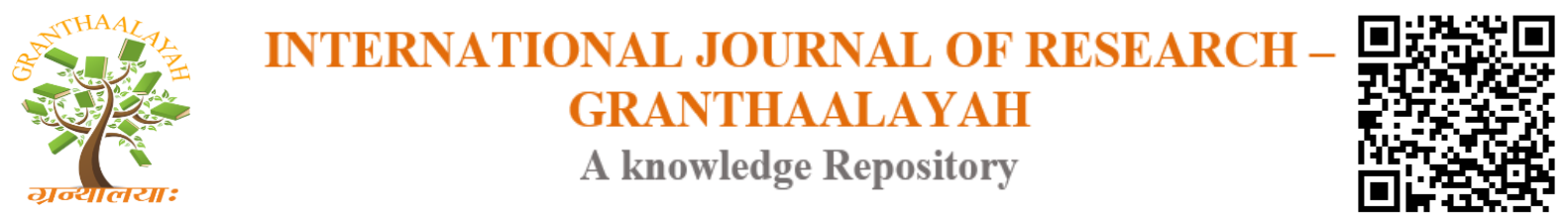

Management

\title{
A CONSUMER BUYING BEHAVIOR WHILE PURCHASING LAPTOPS IN TIRUPATTUR TOWN
}

\author{
M. Saravanan ${ }^{* 1}$ \\ *1 Assistant Professor, Department of Commerce \& Management Studies, \\ Don Bosco College, Guzeou Nagar, Yelagiri Hills, INDIA
}

DOI: https://doi.org/10.29121/granthaalayah.v4.i10(SE).2016.2434

\begin{abstract}
The technology is changing so fast with the development of computer hardware. It has observed that last two decade the purchase of laptop has increased significantly. Now laptop purchase is feeling like purchases of fast moving consuming item. This signifies that the people are very much interested to handle technological instruments in their day to day activities. The laptop is the main sources of communication worth intra and intercommunication among the people. The laptop companies in Tirupattur are interested to study the buying behavior while purchasing towards laptop. In order to develop a framework for the study consumer behavior it is helpful to begin by considering the evolution of the field of consumer research and the different paradigms of thought that have influenced that discipline. As describe in this article, a set of dimensions can be identified in the literature, which can be used to characterize and differentiate, the various perspective on consumer research.
\end{abstract}

Keywords:

Post-Purchase Evaluation, Consumer Behavior, Consumer Attitude.

Cite This Article: M. Saravanan, "A CONSUMER BUYING BEHAVIOR WHILE PURCHASING LAPTOPS IN TIRUPATTUR TOWN" International Journal of Research Granthaalayah, Vol. 4, No. 10: SE (2016): 1-8.

\section{INTRODUCTION}

Computer technology to the consumer market brought with an evolution likes of radios and televisions in the 20th century. It served as a catalyst in jumpstarting not only how consumers obtain information but also the rapidity, quality and density with which they retrieve it. Computers serve as a source of entertainment in addition to its role as resource and productivity tool. The science and Technology are developed in this $21^{\text {st }}$ Era. In this modern world we people give much importance for Electrical and Electronic devices, without that we cannot make our life easier in this busy world. Fast forward from the introduction of the computer to the laptop today, 
where the market has become saturated with well-known brands, each offering nearly indistinguishable products to a population of consumers that are now more educated, informed decision. The study was to determine if a relationship existed between the brand of laptop consumers selected and a variety of demographic and evaluative buying criteria considered in the process. The first of several variables analyzed in this study was the brand of laptop selected in the purchase decision. Additional variables included both tangible, product-related factors like price and features as well as intangible, brand-related attributes like brand image and outside recommendation. The demographic variables examined included age, education level and the degree of technical competence. The result provided laptop vendors a unique perspective on the consideration and selection phase. The results further enabled useful segmentation of the population to better target messaging and promotions that will resonate with the appropriate audience. There is tremendous business value in vendors gaining insight into the consumers' minds around this topic as it can drive better marketing activity to influence awareness, consideration, preference and ultimately purchasing campaigns. While consumers enjoy the benefit of being more educated with public access to free information regarding laptops, manufacturers continue to conduct studies on consumer behaviors behind closed doors.

Little to no market segmentation exist publicly that states that the laptop buyer really is. No public studies had been located at this point of this dissertation development, as market research studies are traditionally private .Have easier access to more information to compare and contrast competitive products and ultimately make a much more fact-based, Laptop is significant in every shops and companies. This unit provides brief insight into the meaning and perspective of Consumer behavior as Well as understanding why it is important to study consumer. The term consumer behavior is defined as the behavior that consumer display in searching for purchasing, using, evaluating and disposing of product and services that they expect will satisfy their needs.

Consumer behavior focuses on how individuals make decisions to spend their available resources (time, money, effort) on consumption related items. This includes what they buy, why they buy it, when they buy it, where they buy it, how often they buy it, how often they use it, how they evaluate it after the purchase and the impact of such evaluation on future, and how they dispose of it. In another words, consumer behavior can be define as the behavior of individuals in regards to acquiring, using, and disposing of products ,services, ideas or experiences. Consumer behavior also includes the Acquisition and use of information. Thus, communication with Consumers and receiving feedback for them is a crucial part of consumer behavior which is of great interest to marketers.

\section{OBJECTIVES OF THE STUDY}

To study the conceptual background with focus on consumer behavior. To find out the sources of information for purchase of laptops. To identify the factors influencing the consumer decision making process. To examine the consumer attitude towards Laptop.

\section{REVIEW OF LITERATURE}

According to louden, D.L. and Della Bitta,A.J., consumer behavior is a decision process and physical activity individuals engage in when evaluating, acquiring, using or disposing of goods and services . 
Peter F. Ducker says, "The purpose of any business is to create a customer. It is the customer who determines what a business it is the customer and he alone, who through being willing to pay for goods or services, converts economic resources into wealth, things into goods. What a business thinks it produces is not of first importance. What the customer thinks he is buyingwhat he considers value, is decisive, it determines what a business is, what it produces and whether it will prosper' therefore, the basic requirement of marketing is to study the consumer/buyer behavior. Dr. Ansir Ali Rajput, Sabir Hussain Kalhoro (2012) presented in this article has significant impact on both price and quality, one thing has been noticed during the survey that people do give more focus to price rather quality because of low income level. People have more alternatives in products that are the reason people go for lower price products. The results clearly indicated that product price has a positive relationship with consumer buying behavior but product quality. Wahida Farzana (2011) this study is to explore how consumers' psychological factors (Motivation, perception, and attitude) are associated with brand equity (brand loyalty, brand association, perceived quality, and brand awareness) of laptop. The result revealed that, consumers' motivation to use laptop and brand association criteria work separately. They consider battery lifetime (brand association) as important feature while satisfying those purposes. Consumers' attitudes are shaped up by others, especially by family members while buying high-involvement products. Respondents show a positive association between their attitudes with one of the highest ranking laptop Apple. Like other products, consumers' perception for choosing laptop relies upon different sources of information. Annamalai Solayappan, Jothi Jayakrishnan (2010) their research showed that branded computers play a prestigious role in the students segment. Due to the computer world everything is in the hands of the students. Everything in the world seems to be digital. Everyone needs a computer to drive a smooth and fast race. Especially, branded computers will try to safeguard the competitive race. So, the various factors discussed may determine the student to purchase branded computers. Lavidge and stenier (2008), proposed such a model for the predictive measurement for advertising effectiveness. They postulated that potential buyer must first be made aware of the existence of a product. During the decision process the individual moves from awareness to the ultimate purchase of the product along a cognitive effective and cognitive dimension of behavior.

\section{METHODOLOGY}

Descriptive research is also known as statistical describes data and characteristics about the population or phenomenon being studies.

\section{DATA COLLECTION}

The researcher used questionnaire for collecting data, for the easy understanding of customer in English version of tool was used for data collection. The data available in the research are both the primary and secondary data. The sampling method used for this project survey is based on statistical sampling method and it is entirely based on convenience of the researcher.

The researcher selected 150 respondents in Tirupattur town.

Number of sampling units selected from the population is used the size of the sample. Sample of 150 respondents were obtained from the population. 


\section{DATA ANALYSIS AND INTERPRETATION}

\section{RESEARCH HYPOTHESES}

To provide focus and direction, three research hypotheses 'null' were formulated for the study. They are as follows.

- There is a significant relationship between family statuses of the respondent to various brands of laptop.

- There is a significant relationship difference between the occupations of the respondents to various brands of laptops.

- There is a significant difference between respondents' occupation to buying laptop.

Family status of the respondent * Various of brands of laptop

\begin{tabular}{|c|c|c|c|c|c|c|c|c|c|}
\hline & & \multicolumn{7}{|c|}{ Various of brands of laptop } & \multirow[b]{2}{*}{ Total } \\
\hline & & Dell & Lenovo & $\begin{array}{l}\text { Toshib } \\
\text { a }\end{array}$ & $\mathrm{HP}$ & Acer & Wipro & Samsung & \\
\hline \multirow{4}{*}{$\begin{array}{l}\text { Family } \\
\text { status of } \\
\text { the } \\
\text { responde } \\
\text { nt }\end{array}$} & $\begin{array}{l}\text { Upper } \\
\text { Clause }\end{array}$ & $\begin{array}{l}(40.7) \\
11 \\
32.35 \\
\end{array}$ & $\begin{array}{l}(7.4) \\
2 \\
8 \% \\
\end{array}$ & $\begin{array}{l}(14.8) \\
4 \\
14.8 \\
\end{array}$ & $\begin{array}{l}(25.92) \\
7 \\
28 \\
\end{array}$ & $\begin{array}{l}(3.5) \\
1 \\
7.1 \\
\end{array}$ & $\begin{array}{l}(7.40) \\
2 \\
15.38 \\
\end{array}$ & 0 & $\begin{array}{l}(100 \%) \\
27 \\
18 \\
\end{array}$ \\
\hline & $\begin{array}{l}\text { Upper } \\
\text { Middle } \\
\text { clause }\end{array}$ & $\begin{array}{l}(20) \\
13 \\
38.23\end{array}$ & $\begin{array}{l}(19.35) \\
12 \\
48\end{array}$ & $\begin{array}{l}(19.35) \\
12 \\
44.44\end{array}$ & $\begin{array}{l}(11.29) \\
7 \\
28\end{array}$ & $\begin{array}{l}(14.5) \\
9 \\
64.2\end{array}$ & $\begin{array}{l}(7.40) \\
2 \\
15.38\end{array}$ & $\begin{array}{l}(11.29) \\
7 \\
58.33\end{array}$ & $\begin{array}{l}(100 \%) \\
62 \\
41.33\end{array}$ \\
\hline & $\begin{array}{l}\text { Middle } \\
\text { clause }\end{array}$ & $\begin{array}{l}(12.9) \\
8 \\
23.50 \\
\end{array}$ & $\begin{array}{l}(20.3) \\
11 \\
44 \\
\end{array}$ & $\begin{array}{l}(18.5) \\
10 \\
37.03 \\
\end{array}$ & $\begin{array}{l}(20.3) \\
11 \\
44.4 \\
\end{array}$ & $\begin{array}{l}(5.5) \\
3 \\
21.42 \\
\end{array}$ & $\begin{array}{l}(14.8) \\
8 \\
61.5 \\
\end{array}$ & $\begin{array}{l}(5.55) \\
3 \\
25 \\
\end{array}$ & $\begin{array}{l}(100 \%) \\
54 \\
36 \\
\end{array}$ \\
\hline & $\begin{array}{l}\text { Lower } \\
\text { clause }\end{array}$ & $\begin{array}{l}(28.5) \\
2 \\
5.88 \\
\end{array}$ & 0 & $\begin{array}{l}(14.2) \\
1 \\
3.7 \\
\end{array}$ & 0 & $\begin{array}{l}(14.28) \\
1 \\
7.14 \\
\end{array}$ & $\begin{array}{l}(14.28) \\
1 \\
7.69 \\
\end{array}$ & $\begin{array}{l}(3.7) \\
2 \\
16.67 \\
\end{array}$ & $\begin{array}{l}(100 \%) \\
7 \\
4.67 \\
\end{array}$ \\
\hline \multicolumn{2}{|l|}{ Total } & $\begin{array}{l}(22.67) \\
34 \\
100 \% \\
\end{array}$ & $\begin{array}{l}(16.67) \\
25 \\
100 \% \\
\end{array}$ & $\begin{array}{l}(18) \\
27 \\
100 \%\end{array}$ & $\begin{array}{l}(16.67) \\
25 \\
100 \%\end{array}$ & $\begin{array}{l}(9.33) \\
14 \\
100 \% \\
\end{array}$ & $\begin{array}{l}(8.67) \\
13 \\
100 \%\end{array}$ & $\begin{array}{l}(8) \\
12 \\
100 \%\end{array}$ & $\begin{array}{l}(100 \%) \\
150 \\
100 \%\end{array}$ \\
\hline
\end{tabular}

\section{Chi-square:}

\begin{tabular}{|l|l|l|}
\hline & Family status of the respondent & Various of brands of laptop \\
\hline Chi-Square & 9.457 & 20.053 \\
Degrees of freedom & 4 & 6 \\
& & \\
\hline
\end{tabular}

A. Have expected frequencies less than 5. The minimum expected cell frequency is 37.5 .

B. Have expected frequencies less than 5. The minimum expected cell frequency is 21.4. 


\section{Hypothesis:}

There is a significant relationship between the occupation of the respondent and various brands of laptop.

Chi-square Calculated value $=9.457$

Degrees of freedom $\mathrm{v}=(\mathrm{n}-1)$

$$
\begin{aligned}
& =4-1 \\
& =3
\end{aligned}
$$

The table value of chi-square at $5 \%$ level $=9.488$

The calculated value is less then table value hence we accepted the null hypothesis. It is provided that there is significant relationship between the occupation of the respondent and various brands of laptop.

\begin{tabular}{|c|c|c|c|c|c|c|c|c|c|}
\hline & & \multicolumn{7}{|c|}{ Various of brands of laptop } & \multirow[b]{2}{*}{ Total } \\
\hline & & dell & Lenovo & $\begin{array}{l}\text { Toshi } \\
\text { ba }\end{array}$ & $\mathrm{HP}$ & Acer & Wipro & Samsung & \\
\hline \multirow{5}{*}{$\begin{array}{l}\text { Occupa } \\
\text { tion of } \\
\text { the } \\
\text { respon } \\
\text { dent }\end{array}$} & $\begin{array}{l}\text { Govt., } \\
\text { employee }\end{array}$ & $\begin{array}{l}(15.5) \\
5 \\
14.70\end{array}$ & $\begin{array}{l}(18.9) \\
7 \\
28\end{array}$ & $\begin{array}{l}(24.32 \\
) \\
9 \\
33.33\end{array}$ & $\begin{array}{l}(18.9) \\
7 \\
28\end{array}$ & $\begin{array}{l}(8.10) \\
3 \\
21.4\end{array}$ & $\begin{array}{l}(5.4) \\
2 \\
15.38\end{array}$ & $\begin{array}{l}(10.8) \\
4 \\
33.33\end{array}$ & $\begin{array}{l}(100 \%) \\
37 \\
24.67\end{array}$ \\
\hline & $\begin{array}{l}\text { Private } \\
\text { employee }\end{array}$ & $\begin{array}{l}(22.4) \\
13 \\
38.23\end{array}$ & $\begin{array}{l}(15.51) \\
9 \\
36\end{array}$ & $\begin{array}{l}(18.96 \\
) \\
11 \\
40.7\end{array}$ & $\begin{array}{l}(13.79) \\
8 \\
32\end{array}$ & $\begin{array}{l}(10.34) \\
6 \\
42.85\end{array}$ & $\begin{array}{l}(8.6) \\
5 \\
38.40\end{array}$ & $\begin{array}{l}(10.34) \\
6 \\
50\end{array}$ & $\begin{array}{l}(100 \%) \\
58 \\
38.67\end{array}$ \\
\hline & $\begin{array}{l}\text { Profession } \\
\text { al }\end{array}$ & $\begin{array}{l}(6.5) \\
8 \\
23.35\end{array}$ & $\begin{array}{l}(7.69) \\
1 \\
4\end{array}$ & $\begin{array}{l}(7.6) \\
1 \\
3.70\end{array}$ & $\begin{array}{l}(5.38) \\
2 \\
8\end{array}$ & 0 & $\begin{array}{l}(7.69) \\
1 \\
7.69\end{array}$ & 0 & $\begin{array}{l}(100 \%) \\
13 \\
8.67\end{array}$ \\
\hline & $\begin{array}{l}\text { Business } \\
\text { people }\end{array}$ & $\begin{array}{l}(0.32) \\
2 \\
5.887 \\
\end{array}$ & $\begin{array}{l}(20) \\
5 \\
20 \\
\end{array}$ & $\begin{array}{l}(16) \\
4 \\
14.8 \\
\end{array}$ & $\begin{array}{l}(24) \\
6 \\
24 \\
\end{array}$ & $\begin{array}{l}(20) \\
5 \\
35.7 \\
\end{array}$ & $\begin{array}{l}(8) \\
2 \\
15.38 \\
\end{array}$ & $\begin{array}{l}4) \\
1 \\
8.33 \\
\end{array}$ & $\begin{array}{l}(100 \%) \\
25 \\
16.67\end{array}$ \\
\hline & Student & $\begin{array}{l}(35.29 \\
) \\
6 \\
17.6\end{array}$ & $\begin{array}{l}(17.6) \\
3 \\
12\end{array}$ & $\begin{array}{l}(11.76 \\
) \\
2 \\
7.40\end{array}$ & $\begin{array}{l}(11.76) \\
2 \\
8\end{array}$ & 0 & $\begin{array}{l}(17.6) \\
3 \\
23.08\end{array}$ & $\begin{array}{l}(5.88) \\
1 \\
8.33\end{array}$ & $\begin{array}{l}(100 \%) \\
17 \\
11.33\end{array}$ \\
\hline \multicolumn{2}{|l|}{ Total } & $\begin{array}{l}(22.67 \\
) \\
34 \\
100 \%\end{array}$ & $\begin{array}{l}(16.67) \\
25 \\
100 \%\end{array}$ & $\begin{array}{l}(18) \\
27 \\
100 \%\end{array}$ & $\begin{array}{l}(16.67) \\
25 \\
100 \%\end{array}$ & $\begin{array}{l}(9.3) \\
14 \\
100 \%\end{array}$ & $\begin{array}{l}(8.67) \\
13 \\
100 \%\end{array}$ & $\begin{array}{l}(8) \\
12 \\
100 \%\end{array}$ & $\begin{array}{l}(100 \%) \\
150 \\
100 \%\end{array}$ \\
\hline
\end{tabular}

\section{Occupation of the respondent * Various of brands of laptop:}

\section{Chi Square Test:}

\begin{tabular}{|l|l|l|}
\hline & Occupation of the Respondent & Various of brands of laptop \\
\hline Chi-Square & 43.867 & 20.053 \\
Degrees of freedom & 4 & 6 \\
\hline
\end{tabular}




\section{Hypothesis:}

There is a significant relationship between the occupation of the respondent and various brands of laptop.

Chi-square Calculated value $=43.867$

Degrees of freedom $\mathrm{v}=(\mathrm{n}-1)$

$$
\begin{aligned}
& =4-1 \\
& =3
\end{aligned}
$$

The table value of chi-square at $5 \%$ level $=9.488$

The calculated value is higher than table value hence we rejected the null hypothesis. It is provided that there is significant relationship between the occupation of the respondent and various brands of laptop.

Chi-square Calculated value $=20.053$

Degrees of freedom $\mathrm{v} \quad=(\mathrm{n}-1)$

$$
\begin{aligned}
& =6-1 \\
& =5
\end{aligned}
$$

The table value of chi-square at $5 \%$ level $=12.592$

The calculated value is higher than table value hence we rejected the null hypothesis. It is

\begin{tabular}{|c|c|c|c|c|c|c|}
\hline & & \multicolumn{4}{|c|}{ Buying Laptop } & \multirow[b]{2}{*}{ Total } \\
\hline & & $\begin{array}{l}\text { Job } \\
\text { Related }\end{array}$ & $\begin{array}{l}\text { Children } \\
\text { Education }\end{array}$ & $\begin{array}{l}\text { Business } \\
\text { Purpose }\end{array}$ & $\begin{array}{l}\text { Any other } \\
\text { specify }\end{array}$ & \\
\hline \multirow{5}{*}{$\begin{array}{l}\text { Occupation of } \\
\text { the respondent }\end{array}$} & $\begin{array}{l}\text { Govt., } \\
\text { employee }\end{array}$ & $\begin{array}{l}(64.86) \\
24 \\
32.4\end{array}$ & $\begin{array}{l}(27.0) \\
10 \\
26.3\end{array}$ & $\begin{array}{l}(8.10) \\
3 \\
10\end{array}$ & 0 & $\begin{array}{l}(100 \%) \\
37 \\
24.67\end{array}$ \\
\hline & $\begin{array}{l}\text { Private } \\
\text { employee }\end{array}$ & $\begin{array}{l}(24.29) \\
31 \\
41.89\end{array}$ & $\begin{array}{l}(37.93) \\
22 \\
57.89\end{array}$ & $\begin{array}{l}(1.72) \\
1 \\
3.33\end{array}$ & $\begin{array}{l}(6.89) \\
4 \\
50 \\
\end{array}$ & $\begin{array}{l}(100 \%) \\
58 \\
38.67\end{array}$ \\
\hline & Professional & $\begin{array}{l}(12.06) \\
7 \\
9.05\end{array}$ & $\begin{array}{l}(15.38) \\
2 \\
5.26\end{array}$ & $\begin{array}{l}(23.02) \\
3 \\
10\end{array}$ & $\begin{array}{l}(7.69) \\
1 \\
12.5 \\
\end{array}$ & $\begin{array}{l}(100 \%) \\
13 \\
8.67\end{array}$ \\
\hline & $\begin{array}{l}\text { Business } \\
\text { people }\end{array}$ & $\begin{array}{l}(8) \\
2 \\
2.7 \\
\end{array}$ & $\begin{array}{l}(8) \\
2 \\
5.26 \\
\end{array}$ & $\begin{array}{l}84) \\
21 \\
70 \\
\end{array}$ & 0 & $\begin{array}{l}(100 \%) \\
25 \\
16.67 \\
\end{array}$ \\
\hline & Student & $\begin{array}{l}(58.02) \\
10 \\
13.5\end{array}$ & $\begin{array}{l}(11.76) \\
2 \\
5.26\end{array}$ & $\begin{array}{l}11.76 \\
2 \\
6.67\end{array}$ & $\begin{array}{l}17.64 \\
3 \\
37.5\end{array}$ & $\begin{array}{l}(100 \%) \\
17 \\
11.35\end{array}$ \\
\hline \multicolumn{2}{|l|}{ Total } & $\begin{array}{l}(49.33) \\
74 \\
100 \%\end{array}$ & $\begin{array}{l}(25.30) \\
38 \\
100 \%\end{array}$ & $\begin{array}{l}(20) \\
30 \\
100 \% \\
\end{array}$ & $\begin{array}{l}(5.33) \\
8 \\
100 \% \\
\end{array}$ & $\begin{array}{l}(100 \%) \\
150 \\
100 \% \\
\end{array}$ \\
\hline
\end{tabular}
provided that there is significant relationship between the occupation of the respondent and various brands of laptop.

\section{Occupation of the respondent * Buying Laptop:}




\section{Chi-square test:}

\begin{tabular}{|l|l|l|}
\hline & $\begin{array}{l}\text { Occupation of the } \\
\text { Respondent }\end{array}$ & Buying laptop \\
\hline $\begin{array}{l}\text { Chi-Square } \\
\text { Degrees of freedom }\end{array}$ & 43.867 & 8.675 \\
& 4 & 5 \\
\hline
\end{tabular}

\section{Hypothesis:}

There is a significant relationship between the occupations of the respondent buying laptop.

Chi-square Calculated value $=43.867$

Degrees of freedom $\mathrm{v}=(\mathrm{n}-1)$

$$
\begin{aligned}
& =4-1 \\
& =3
\end{aligned}
$$

The table value of chi-square at $4 \%$ level $=9.488$

The calculated value is higher than table value hence we rejected the null hypothesis. It is provided that there is significant relationship between the occupation of the respondent and buying laptop.

Chi-square Calculated value $=9.457$

Degrees of freedom $\mathrm{v} \quad=(\mathrm{n}-1)$

$$
\begin{aligned}
& =5-1 \\
& =4
\end{aligned}
$$

The table value of chi-square at $5 \%$ level $=11.070$

The calculated value is less then table value hence we accepted the null hypothesis. It is provided that there is significant relationship between the occupation of the respondent and various brands of laptop.

\section{CONCLUSION}

It is further investigated that most of the respondents Level of satisfaction regards to price, delivery, quality, style and after sale service is good they ready to recommend the product to others. To-day there is numbers of brands available in the market and they differ in prices, quality, capacity, type etc. in the present technological era, it can be easily said that all middle class people using laptops to replacing human resources. By considering this situation consumer durable products have come up with different names. But consumer prefers to purchase their brands due to various reasons. It is obvious that the brand name. quality, price, capacity, style features, Guarantee/Warranty, after sales service, cash discount, installment system together decided the purchase. So the manufactures shall pay special attention to the above factors and to all problems revealed by the customer. If these things have been seriously considered by manufactures of laptops, their business will up and they can enjoy with good amount of goodwill. To rightly say, yesterday's Luxuries are today's necessities. Hence in this digital world, laptops are no longer a luxury item. 


\section{REFERENCES}

[1] Aswathappa K,(1999) Business environment, sixth edition, Himalaya publishing House.

[2] Aswattapa K, "organizations behavior, "Himalaya Publishing House, Bombay, 1998.

[3] Baker M J, (1991) sampling in Research for marketing Macmillan, London, pp 100-113,

[4] Basu C.R. ., (1998) Multinational Enterprise, Business Organization and Management ,Tata MC. Graw-Hill publishing company Ltd.

[5] C. L. Tyagi / Arun kumar, Consumer Behaviour Atlantic publishers and Distributors.

[6] Cohen J. (1988). Statistical power analysis (2nded). Hillsdale, NJ: Erlbaum.

[7] Donald R. cooper and Pamela S. scchindler, (200), Business research Methods. Sixth Edition, Tata M C Graw-Hill, PP.11-1

[8] Dr. Rajeev kumra, Consumer Behaviour Himalaya publishing house.

[9] Dr. Gupta S.L, Sumitra Pal, " consumer behavior, an Indian perspective text\& cases," Edition 2002,

[10] Dr. Mallikarjuna Reddy K, "Marketing strategy Linkages with Consumers Behavior," Indian Journal of marketing, vol. XXXII, March-April 2002.

[11] Dr. Sivakumar, Komathi s, "consumer Behavior towards laptops an Exploratory study with Reference to Pondicherry Region," Indian Journal of Marketing, Vol.XXXIV, May 2004.

[12] Gandhi.J.C, Marketing, Twelfth Reprint, Tata Mc-Graw Hill publications, New Delhi, 1998.

[13] Golden, S. A. R. (2015). Regional Imbalance affecting quality of e-banking services with special reference to Tuticorin District-An Analysis. International Journal of Research, 2(3), 788-798.

[14] K. K. Srivastara, sujate khandai Consumer Behaviour, In Indian Context

[15] Regi, S. B. (2016). Prospectus \& Challenges Of Women Entrepreneurs-A Study With Special Reference To Tirunelveli District. International Journal Of Scientific Research And Modern Education, 786, 792.

[16] Regi, S. B., \& Golden, S. A. R. (2014). A Descriptive Study On The Role Of Consumer Psychology And Behaviour In Product Purchasing. Indian Streams Research Journal, 3 (12), $1,6$.

[17] Regi, S. B., Golden, S. A. R., \& Franco, C. E. (2014). A DESCRIPTIVE STUDY ON THE PROSPECTS OF E-COMMERCE IN INDIA. Golden Research Thoughts, 3 (9), 1, 7.

[18] Sheetal Kapoor, "understanding buying behavior of Indian Families, "New Centaury publications, New Delhi.

[19] Suja R.Nair, "consumer behavior In Indian perspective," Himalaya Publishing House, Bombay. 